\title{
ISOLATION OF ACTINOMYCETES FROM THE SEDIMENTS OF PICHAVARAM MANGROVE FOREST, SOUTH INDIA AND ANALYSING THEIR ANTIBACTERIAL EFFICACY
}

\author{
AARTHI $M^{1,2}$, KAMALANATHAN $\mathrm{D}^{2}$, BALAKRISHNAN $\mathrm{V}^{1,3 *}$ \\ ${ }^{1}$ Research and Development Centre, Bharathiar University, Coimbatore, Tamil Nadu, India. ${ }^{2}$ Department of Biotechnology, K. S. Rangasamy \\ College of Arts and Science (Autonomous), Tiruchengode, Tamil Nadu, India. ${ }^{3}$ Department of Botany, Arignar Anna Government Arts \\ College, Namakkal, Tamil Nadu, India. Email: palanivbalu@gmail.com
}

Received: 24 December 2019, Revised and Accepted: 20 February 2020

ABSTRACT

Objective: The aim of the present investigation is to isolate actinomycetes from the sediments of Pichavaram mangrove forest, South India, and to screen for their antibacterial efficiency.

Methods: Actinomycetes were isolated by culturing the samples in Starch Casein Agar medium; they were screened primarily for their antibacterial efficiency against Gram-positive and Gram-negative bacterial organisms. Solvent extraction was done with $50 \%$ (percentage) ethyl acetate, crude extracts of actinomycetes were prepared at different concentrations using dimethyl sulfoxide and treated against the bacterial organisms. Antibacterial assay was done in Mueller-Hinton agar medium.

Results: Thirteen actinomycetes were isolated; among them, four actinomycete isolates (Pichavaram mangrove actinomycete 2 [PMA2], PMA6, PMA9, and PMA13) exhibited antibacterial activity.

Conclusion: Isolate PMA2 exhibited very strong antibacterial activity and isolate PMA13 is weakly active against the tested bacterial organisms.

Keywords: Actinomycetes, Starch casein agar medium, Salinity, Crude extract, Antibacterial efficiency, Antibacterial assay.

(C) 2020 The Authors. Published by Innovare Academic Sciences Pvt Ltd. This is an open access article under the CC BY license (http://creativecommons. org/licenses/by/4. 0/) DOI: http://dx.doi.org/10.22159/ajpcr.2020.v13i4.36702

\section{INTRODUCTION}

Coastal region is an important region for human beings since the beginning of time. Coastal ecosystem supports coral reefs, seagrasses, marine biota, and the growth of mangrove forest. Mangroves are the most important ecosystems of coastal and marine region. Mangrove forests provide direct and indirect contributions to human beings and natural habitats in the ocean. Soil microbes are important sources for displaying great biological activity against several pathogens. Bioactive molecules are capable of modulating metabolic process and they exhibit beneficial effects such as antioxidant activity, inhibition or induction of enzymes, inhibition of receptor activities, and induction and inhibition of gene expression. They are also useful for the protectionmechanism [1].Actinomycetes havemorevaluebotheconomically and biotechnologically which can produce $80 \%$ of total available antibiotics in the world. The most important genera for the production of antibiotics are Streptomyces and Micromonospora [2]. Actinomycetes exist in various places of environment, including soil, freshwater, and marine water environments. The biologically active terrestrial compounds are overexploited, so the search for the new compounds has been increased toward the marine ecosystem. Marine actinomycetes are different from terrestrial actinomycetes both phylogenetically and physiologically [3]. The marine sediments are capable of synthesizing bioactive secondary metabolites [4,5]. In 2014, the World Health Organization (WHO) reported that the resistance toward antimicrobials has developed much and it is the major challenge to overcome this problem. The WHO also promotes the medicinal sources from the traditional medicinal system [6]. Hence, the study was aimed to screen antibacterial efficiency by producing bioactive natural compounds from the actinomycetes isolated from the sediments of Pichavaram Mangrove Forest, South India.

\section{METHODS}

\section{Sample collection}

The water and sediment samples were collected from the mangrove forest in Thandavarayan Sholagan Pet, Chidambaram Taluk, Cuddalore district, Tamil Nadu, South India. The geographical location is shown in Fig. 1.

The field is situated in $11.41^{\circ} \mathrm{N}$ (North) latitude and $79.79^{\circ} \mathrm{E}$ (East) longitude at an altitude of above +5.25 M (meter) mean sea level. The water samples were collected in polypropylene tubes and the sediment samples were collected in plastic bags at five different locations at a depth of one feet each $[7,8]$. The samples were collected at 7.00 a.m. (ante meridian) during winter season. During sample collection, the sample temperature and $\mathrm{pH}$ were tested. Then, the samples were brought to the laboratory and stored at $4^{\circ} \mathrm{C}$ [9].

\section{Salinity test (total dissolved salts [TDS])}

To find TDS, $100 \mathrm{ml}$ of water sample was evaporated in a hot air oven. Then, the salt settled at the bottom was measured. The tests were done twice and the average value has been taken [10].

\section{Isolation of actinomycetes}

The samples were diluted serially in the water brought from the mangrove forest and $10^{-4}$ diluted sample was plated on starch casein agar medium [10]. The media were supplemented with cycloheximide $(25 \mu \mathrm{g} / \mathrm{ml})$ and nalidixic acid $(25 \mu \mathrm{g} / \mathrm{ml})$ for the inhibition of fungi and Gram-negative bacteria, respectively. The plates were incubated for 7 days at $30^{\circ} \mathrm{C}$ [9]. The actinomycetes were used against Gram-positive and Gramnegative bacterial organisms to screen their antibacterial efficiency [7].

\section{Test bacterial organisms}

Antibacterial susceptibility was detected against ten bacterial strains of the Microbial Type Culture Collection and Gene Bank and listed in Table 1 [11]. Among ten bacterial organisms, each five bacterial organisms are Gram-positive and Gram-negative organisms [12-14].

\section{Screening for the antibacterial efficiency}

The antibacterial efficiencies of actinomycete isolates were determined against ten bacterial strains. The actinomycete sample 


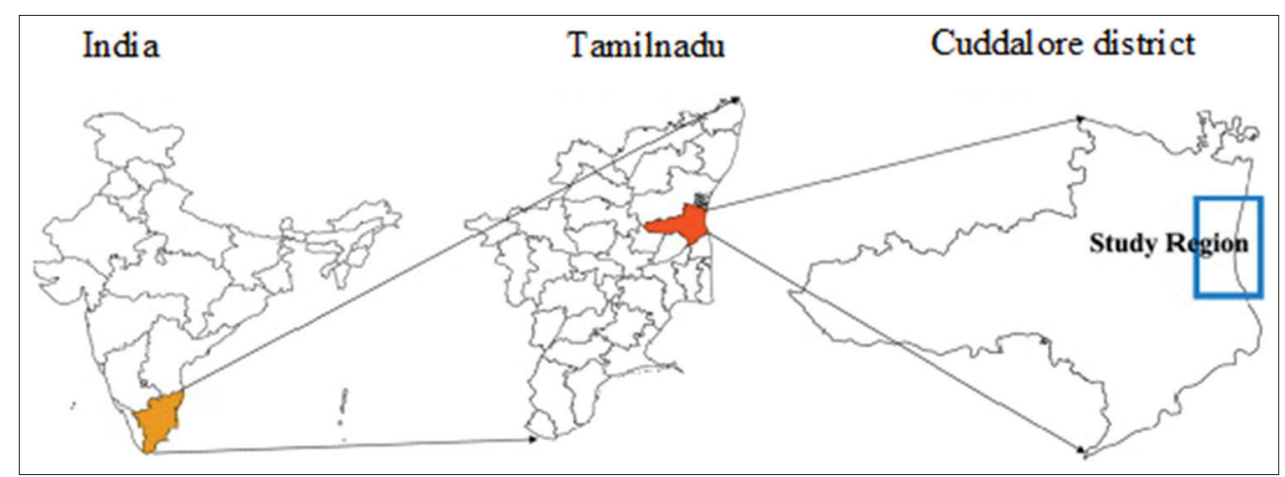

Fig. 1: Geographical location of Thandavarayan Sholagan Pet, South India. Tamil Nadu state has been marked in India; it has been maximized to show its districts. In Tamil Nadu state, Cuddalore district has been shaded and maximized to show the study region Thandavarayan Sholagan Pet ( $\square$ blue color box)

Table 1: List of bacterial organisms used for screening antibacterial efficacy

\begin{tabular}{|c|c|c|c|}
\hline $\begin{array}{l}\text { Type of bacterial } \\
\text { organism }\end{array}$ & $\begin{array}{l}\text { Name of the } \\
\text { organism }\end{array}$ & Abbreviation & $\begin{array}{l}\text { MTCC } \\
\text { number }\end{array}$ \\
\hline \multirow{5}{*}{$\begin{array}{l}\text { Gram-positive } \\
\text { organisms }\end{array}$} & Bacillus subtilis & $B s$ & MTCC 1133 \\
\hline & B. megaterium & $B m$ & MTCC 2949 \\
\hline & B. cereus & $B c$ & MTCC 430 \\
\hline & $\begin{array}{l}\text { Staphylococcus } \\
\text { aureus }\end{array}$ & $\mathrm{Sa}$ & MTCC 3160 \\
\hline & S. epidermidis & $\mathrm{Se}$ & MTCC 3382 \\
\hline \multirow{5}{*}{$\begin{array}{l}\text { Gram-negative } \\
\text { organisms }\end{array}$} & Escherichia coli & $E c$ & MTCC 1692 \\
\hline & Salmonella typhi & Sti & MTCC 3216 \\
\hline & $\begin{array}{l}\text { Salmonella } \\
\text { typhimurium }\end{array}$ & Stm & MTCC 3214 \\
\hline & $\begin{array}{l}\text { Pseudomonas } \\
\text { aeruginosa }\end{array}$ & $P a$ & MTCC 2581 \\
\hline & $\begin{array}{l}\text { Klebsiella } \\
\text { pneumoniae }\end{array}$ & Kp & MTCC 2653 \\
\hline
\end{tabular}

was streaked linearly on the surface of nutrient agar medium exactly at the center and incubated for 7 days at $37^{\circ} \mathrm{C}$. The bacterial organisms were inoculated on both sides perpendicularly to the actinomycetes at the distance of $5 \mathrm{~mm}$ (millimeter) from the actinomycete [15]. The Gram-negative organisms were streaked on one side and the Gram-positive organisms were on the other side and incubated for $48 \mathrm{~h}$ at $37^{\circ} \mathrm{C}[7,13]$.

\section{Antibacterial assay}

Solvent extraction was done with 50\% ethyl acetate and diluted in dimethyl sulfoxide for the preparation of different concentrated crude extracts of all the four actinomycetes [12]. The antibacterial activities of the actinomycetes were assessed against ten bacterial organisms using well diffusion assay. Mueller-Hinton agar plates were prepared and swabbed with the bacterial organisms. Four wells were made in $6 \mathrm{~mm}$ diameter each [16]. The different concentrated crude extract was loaded in all wells in $100 \mu \mathrm{l}$ volume. The plates were incubated at $37^{\circ} \mathrm{C}$ for overnight. The antibacterial activity was then recorded as growth free inhibition zones around the well [17]. The experiments were repeated up to 3 times to find the mean value.

\section{RESULTS}

\section{Sample collection}

The water and sediment samples were collected from the mangrove forest in Thandavarayan Sholagan Pet, South India. During sample collection, the temperature and $\mathrm{pH}$ were verified. The temperature was $28^{\circ} \mathrm{C}$ and the $\mathrm{pH}$ was 7.2 .

\section{Salinity test}

To find TDS, $100 \mathrm{ml}$ of water sample was evaporated in a hot air oven. The salt settled at the bottom was weighed. It was $2.3 \mathrm{~g}$; therefore, TDS of the water was calculated as $2.3 \%$.

\section{Isolation of actinomycetes}

A total of 13 actinomycetes were isolated based on different colony morphology from the samples collected at five different locations. The actinomycetes were named as isolate Pichavaram mangrove actinomycete 1 (PMA1) to isolate PMA13. The colony morphology of the actinomycete isolates was listed in Table 2.

\section{Screening for the antibacterial efficiency}

Isolate PMA2 has strong activity on Bacillus megaterium, mild activity on Bacillus subtilis, Bacillus cereus, Staphylococcus aureus, Staphylococcus epidermidis, Escherichia coli, Salmonella typhi, Salmonella typhimurium, and Pseudomonas aeruginosa. Isolate PMA2 has no activity on Klebsiella pneumoniae.

Strong activity was shown by isolate PMA6 on B. megaterium, S. aureus, Salmonella typhi, and Salmonella typhimurium. Mild activity was shown on S. epidermidis. Mild or nil activity was shown on B. cereus. There was no activity against B. subtilis, E. coli, P. aeruginosa, and K. pneumoniae.

Isolate PMA9 has shown strong antibacterial activity on $S$. aureus, mild activity on B. megaterium, B. cereus, S. epidermidis, P. aeruginosa, Salmonella typhi, and Salmonella typhimurium. Isolate PMA9 was not shown the activity against B. subtilis, E. coli, and K. pneumoniae.

Isolate PMA13 was showing mild activity on S. epidermidis. The rest of the bacterial organisms were resistant toward the isolate PMA13. The antibacterial efficiency of actinomycetes is shown in Table 3.

\section{Antibacterial assay}

Isolate PMA2

Isolate PMA2 has produced $17 \pm 0.62 \mathrm{~mm}$ diameter zone of inhibition on B. megaterium with $1.43 \%$ of crude extract and $25 \pm 0.7 \mathrm{~mm}$ diameter zone of inhibition with the same organism at the concentration of $2.86 \%$. It also produced $15 \pm 0.66 \mathrm{~mm}, 17 \pm 0.99 \mathrm{~mm}$, and $19 \pm 0.7 \mathrm{~mm}$ diameter zone of inhibition on S. aureus at the concentrations of $1.43 \%$, $2.145 \%$, and $2.86 \%$, respectively.

Even at the concentration of $<1 \%(0.715 \%)$, isolate PMA2 produced $15 \pm 0.65 \mathrm{~mm}$ and $14 \pm 0.53 \mathrm{~mm}$ diameter zone of inhibition on $E$. coli and Salmonella typhi, respectively. Furthermore, it has produced $17 \pm 0.74 \mathrm{~mm}, 20 \pm 0.5 \mathrm{~mm}$, and $24 \pm 0.98 \mathrm{~mm}$ diameter zone of inhibition on $E$. coli at the concentrations of $1.43 \%, 2.145 \%$, and $2.86 \%$, respectively. It also produced $22 \pm 0.45 \mathrm{~mm}, 23 \pm 0.37 \mathrm{~mm}$, and $26 \pm 0.71 \mathrm{~mm}$ diameter zone of inhibition on Salmonella typhi at the concentrations of $1.43 \%, 2.145 \%$, and $2.86 \%$, respectively. Isolate 
Table 2: Colony morphology of the actinomycetes from soil sediments of Pichavaram mangrove forest, South India

\begin{tabular}{ll}
\hline Isolate & Morphology \\
\hline PMA1 & Slightly white with small colonies \\
PMA2 & Yellow with small colonies \\
PMA3 & Ash color \\
PMA4 & Slightly black and slightly pink \\
PMA5 & Ash color \\
PMA6 & Slightly yellow \\
PMA7 & Light pink \\
PMA8 & Light green \\
PMA9 & Slightly yellow with small colonies \\
PMA10 & Slightly pink \\
PMA11 & Light yellow with small colonies \\
PMA12 & Pale white with large colonies \\
PMA13 & Slightly black with large colonies \\
\hline
\end{tabular}

PMA: Pichavaram mangrove actinomycete

Table 3: Antibacterial efficiency of actinomycetes from soil sediments of Pichavaram mangrove forest, South India

\begin{tabular}{|c|c|c|c|c|c|c|c|c|c|c|}
\hline \multirow[t]{3}{*}{ Actinomycetes } & \multicolumn{10}{|c|}{ Bacterial organisms } \\
\hline & \multicolumn{5}{|c|}{$\begin{array}{l}\text { Gram-positive } \\
\text { organisms }\end{array}$} & \multicolumn{5}{|c|}{$\begin{array}{l}\text { Gram-negative } \\
\text { organisms }\end{array}$} \\
\hline & $B s$ & $B m$ & $B c$ & Sa & $S e$ & $E c$ & $P a$ & Sti & Stm & $K p$ \\
\hline PMA1 & - & - & - & - & - & - & - & - & - & - \\
\hline PMA2 & + & ++ & + & + & + & + & + & + & + & - \\
\hline PMA3 & - & - & - & - & - & - & - & - & - & - \\
\hline PMA4 & - & - & - & - & - & - & - & - & - & - \\
\hline PMA5 & - & - & - & - & - & - & - & - & - & - \\
\hline PMA6 & - & ++ & $-/+$ & ++ & + & - & - & ++ & ++ & - \\
\hline PMA7 & - & - & - & - & - & - & - & - & - & - \\
\hline PMA8 & - & - & - & - & - & - & - & - & - & - \\
\hline PMA9 & - & + & + & ++ & + & - & + & + & + & - \\
\hline PMA10 & - & - & - & - & - & - & - & - & - & - \\
\hline PMA11 & - & - & - & - & - & - & - & - & - & - \\
\hline PMA12 & - & - & - & - & - & - & - & - & - & - \\
\hline PMA13 & - & - & - & - & + & - & - & - & - & - \\
\hline
\end{tabular}

-: Not detected, +: Mild activity, ++: Strong activity, /: or The actinomycetes PMA2, PMA6, PMA9, and PMA13 were actively performing antibacterial activity and these four actinomycetes were taken for further studies. PMA: Pichavaram mangrove actinomycete
PMA2 produced $16 \pm 0.81 \mathrm{~mm}$ and $19 \pm 0.43 \mathrm{~mm}$ diameter zone of inhibition on Salmonella typhimurium and $10 \pm 0.7 \mathrm{~mm}$ and $12 \pm 0.88 \mathrm{~mm}$ diameter zone of inhibition on $K$. pneumonia at the concentrations of $2.145 \%$ and $2.86 \%$, respectively. The diameter of the zone of inhibition produced by isolate PMA2 is shown in Fig. 2.

Isolate PMA2 has higher inhibitory activity on the bacterial organisms Salmonella typhi, B. megaterium, E. coli, S. aureus, and Salmonella typhimurium. It has mild inhibitory activity on $K$. pneumoniae. It has not produced any zone of inhibition on B. subtilis, B. cereus, S. epidermis, and $P$. aeruginosa.

\section{Isolate PMA6}

Isolate PMA6 has strong antibacterial activity on $B$. megaterium $(18 \pm 1.16 \mathrm{~mm}), B$. cereus $(19 \pm 0.82 \mathrm{~mm}), S$. aureus $(18 \pm 0.62 \mathrm{~mm})$, and Salmonella typhi $(19 \pm 0.33 \mathrm{~mm})$. Mild activity was shown against Salmonella typhimurium $(13 \pm 0.9 \mathrm{~mm}), P$. aeruginosa $(12 \pm 0.5 \mathrm{~mm})$, and K. pneumonia $(10 \pm 0.57 \mathrm{~mm})$. The activity was not detected against B. subtilis, S. epidermidis, and E. coli. These activities were shown at its higher concentrated (3.52\%) crude extracts. At the concentration of $2.64 \%$ crude extract, $16 \pm 0.7 \mathrm{~mm}, 17 \pm 0.36 \mathrm{~mm}, 15 \pm 0.73 \mathrm{~mm}$, $19 \pm 0.7 \mathrm{~mm}$, and $10 \pm 0.56 \mathrm{~mm}$ diameter zone of inhibitions were recorded against B. megaterium, B. cereus, S. aureus, Salmonella typhi, and Salmonella typhimurium, respectively. There was no zone of inhibition against the rest of the bacterial organisms at $2.64 \%$ crude extract. $16 \pm 0.56 \mathrm{~mm}, 13 \pm 0.31 \mathrm{~mm}$, and $12 \pm 0.21 \mathrm{~mm}$ diameter zone of inhibitions were recorded against B. cereus, S. aureus, and Salmonella typhi at $1.76 \%$ of crude extract. The rest of the bacterial organisms were not inhibited at $1.76 \%$ of crude extract. Even at the Concentration of $<1 \%(0.88 \%)$, isolate PMA6 could able to produce a zone of inhibitions in the diameter of $12 \pm 0.6 \mathrm{~mm}$ and $11 \pm 0.4 \mathrm{~mm}$ against $B$. cereus and $S$. aureus, respectively. The diameter of the zone of inhibition produced by the isolate PMA6 is given as Fig. 3.

\section{Isolate PMA9}

Isolate PMA9 has shown highestzone of inhibition against B. megaterium, they were recorded as $10 \pm 0.42 \mathrm{~mm}, 16 \pm 0.56 \mathrm{~mm}$, and $18 \pm 0.56 \mathrm{~mm}$ at the concentrations of $1.76 \%, 2.64 \%$, and $3.52 \%$, respectively. The mild activity was shown against $S$. aureus, the zones of inhibitions were recorded as $10 \pm 0.56 \mathrm{~mm}, 10 \pm 0.66 \mathrm{~mm}, 12 \pm 0.59 \mathrm{~mm}$, and $12 \pm 0.61 \mathrm{~mm}$ at the concentrations of $0.88 \%, 1.76 \%, 2.64 \%$, and $3.52 \%$, respectively. At the concentrations of $3.52 \%$ and $2.64 \%$, the zones of inhibitions were recorded as $10 \pm 0.45 \mathrm{~mm}$ and $8 \pm 0.7 \mathrm{~mm}$ against $S$. epidermidis

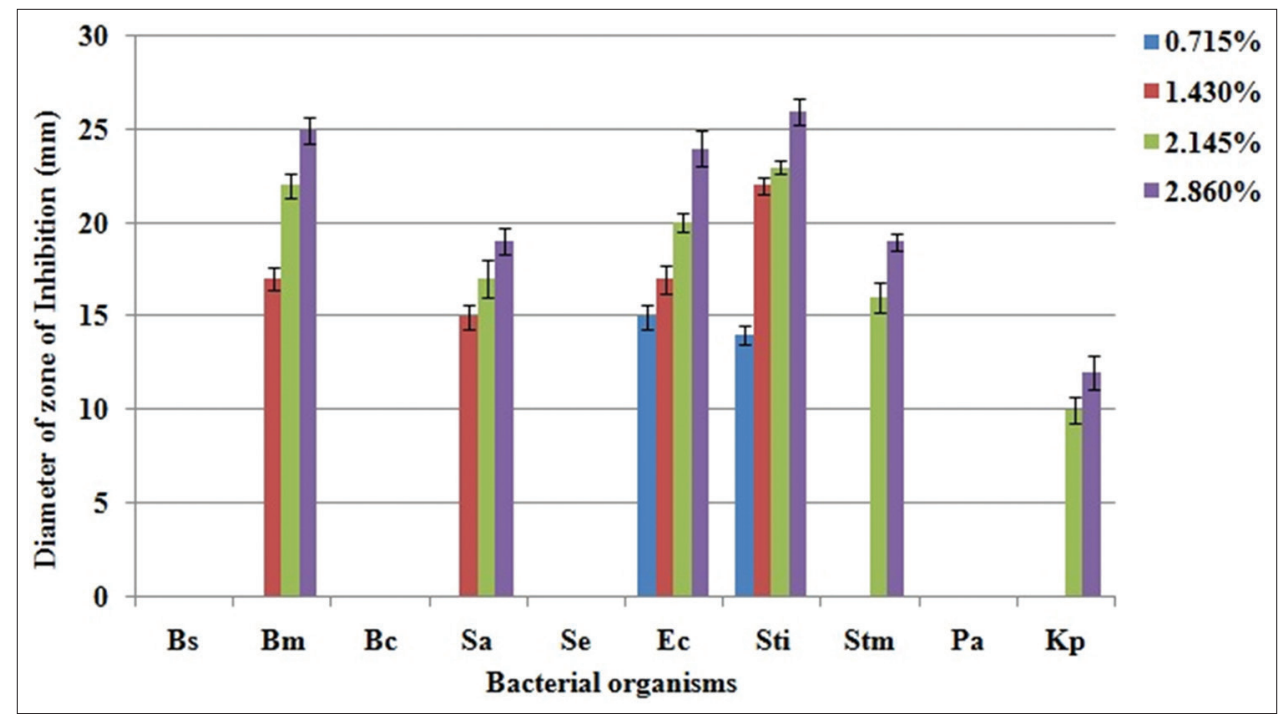

Fig. 2: Graphical representation of antibacterial assay of isolate Pichavaram mangrove actinomycete 2 isolated from soil sediments of Pichavaram mangrove forest. All the experiments were performed in triplicates and mean value was calculated by the standard deviation (SD) (mean value \pm SD) 
and $15 \pm 0.74 \mathrm{~mm}$ and $11 \pm 0.36 \mathrm{~mm}$ against Salmonella typhimurium. The antibacterial activity was not detected against B. subtilis, B. cereus, E. coli, Salmonella typhi, P. aeruginosa, and K. pneumonia. The diameter of the zone of inhibition produced by PMA9 is shown in Fig. 4.

\section{Isolate PMA13}

Isolate PMA13 has Mild antibacterial activity against $B$. megaterium, the zones of inhibitions were recorded as $10 \pm 0.22 \mathrm{~mm}, 10 \pm 0.49 \mathrm{~mm}$, $15 \pm 0.6 \mathrm{~mm}$ and $14 \pm 0.79 \mathrm{~mm}$ at the concentrations of $0.175 \%, 1.43 \%$, $2.145 \%$, and $2.86 \%$. At the concentration of $2.86 \%, 8 \pm 0.56 \mathrm{~mm}$ zone of inhibition was recorded against $B$. cereus. Isolate PMA13 was active against $S$. aureus, produced $8 \pm 0.57 \mathrm{~mm}$ and $8 \pm 0.19 \mathrm{~mm}$ zones of inhibitions at the concentrations of $2.145 \%$ and $2.86 \%$, respectively. $12 \pm 0.38 \mathrm{~mm}$ and $8 \pm 0.33 \mathrm{~mm}$ zones of inhibitions were recorded against E. coli at the concentrations of $2.145 \%$ and $2.86 \%$, respectively. The activity was not detected against B. subtilis, S. epidermidis, Salmonella typhi, Salmonella typhimurium, P. aeruginosa, and K. pneumonia. The diameter of the zone of inhibition produced by PMA13 is shown in Fig. 5.

\section{DISCUSSION}

Actinomycetes exist in most of the places of nature and they possess the ability of synthesizing several biologically active compounds such as antibacterial, antifungal, antiviral, antiparasitic, herbicides, pesticides, antioxidant, and anti-tumor [1]. We examined the ability of actinomycetes from the sediments of Pichavaram mangrove forest to for their antibacterial efficacy.

In our study, a total of 13 actinomycetes were isolated from five different locations of Pichavaram mangrove forest and perpendicular streaking was done to find out the antibacterial efficiency against ten bacterial organisms. One hundred six actinomycetes were isolated from five different soil samples. These actinomycetes were cross streaked against microbial pathogens [1].

Plant sources contain good bioactive molecules and it acts as a source of antimicrobial and antioxidant agents [18-21]. Allium cepa possess bioactive natural products and might be used for the treatment of infectious diseases of bacteria [22]. The growth of Salmonella bacteria Thy 1 was inhibited in vivo and it has proved that manila extract has the

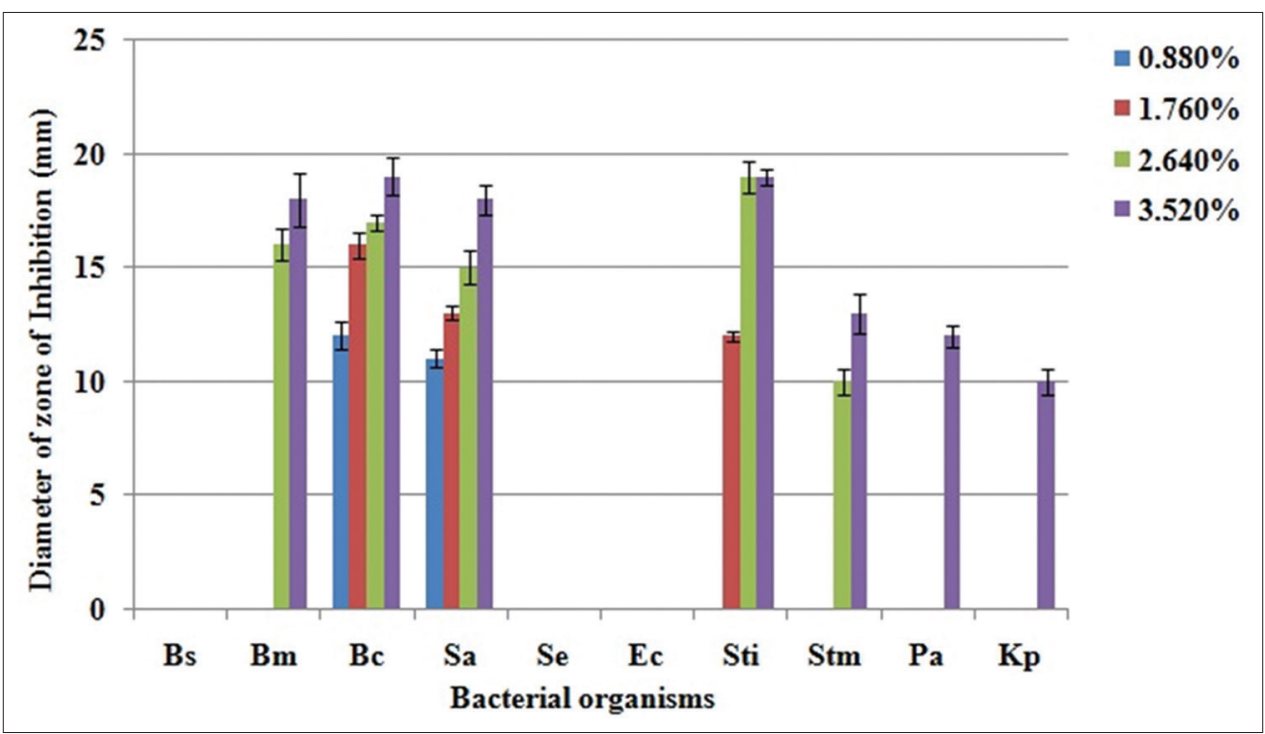

Fig. 3: Graphical representation of antibacterial assay of isolate Pichavaram mangrove actinomycete 6 isolated from soil sediments of Pichavaram mangrove forest. All the experiments were performed in triplicates and mean value was calculated by the standard deviation (SD) (mean value \pm SD)

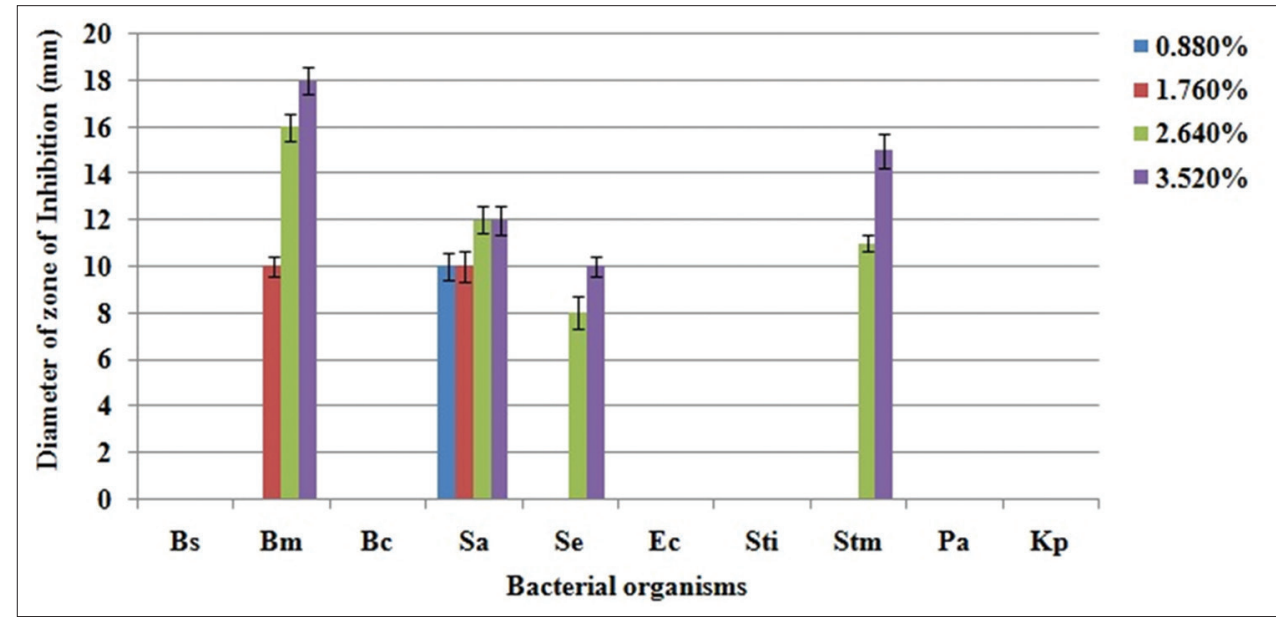

Fig. 4: Graphical representation of antibacterial assay of isolate Pichavaram Mangrove Actinomycete 9 isolated from soil sediments of Pichavaram mangrove forest. All the experiments were performed in triplicates and mean value was calculated by the standard deviation (Mean value \pm SD) 


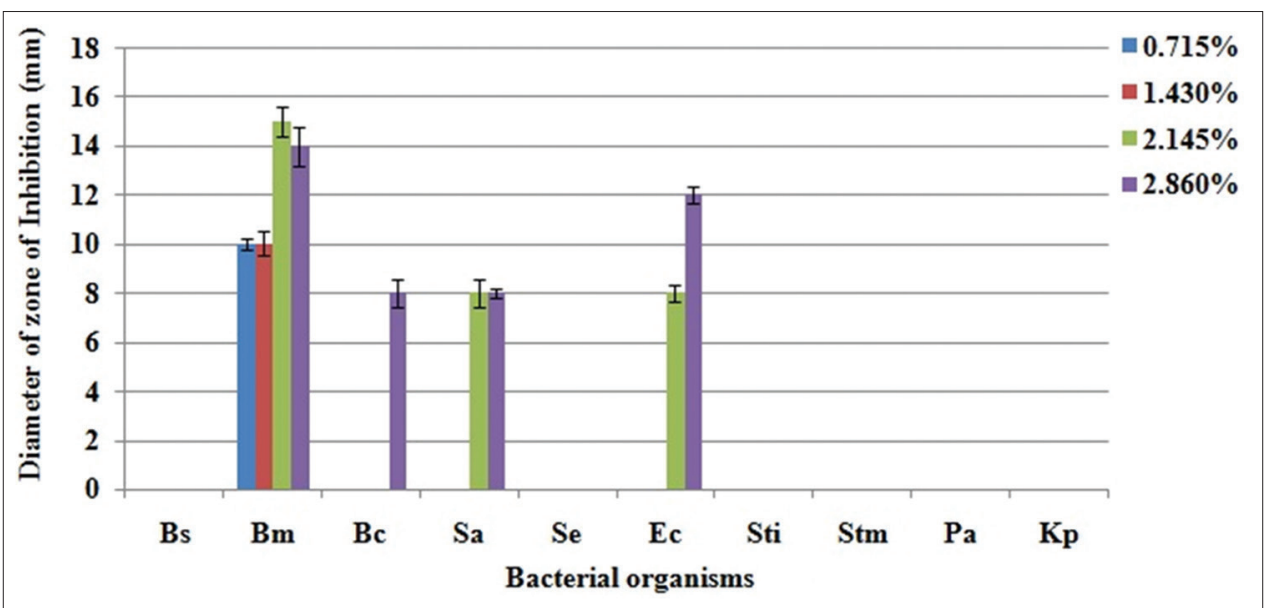

Fig. 5: Graphical representation of antibacterial assay of isolate Pichavaram mangrove actinomycete 13 isolated from soil sediments of Pichavaram mangrove forest. All the experiments were performed in triplicates and mean value was calculated by the standard deviation (SD) (mean value \pm SD)

capability for the inhibition [23]. Ethanol extract of turmeric, cinnamon, and clove was tested against E. coli and S. aureus. These two bacterial organisms are sensitive to all three plants; cinnamon is more active than the other two plants [24].

The primary screening for the antagonistic activity of actinomycetes showed antibacterial activity against both Gram-positive and Gram-negative bacterial organisms [3]. In the same way, the actinomycetes were streaked perpendicularly and they acted against Gram-positive and Gram-negative bacterial organisms. This revealed that the actinomycetes produce antibacterial compound against both Gram-positive and Gram-negative bacterial organisms.

Out of 13 actinomycetes isolates, only $4(31 \%)$ actinomycetes were able to produce antibacterial compound. Thirty actinomycetes were examined, of this, only $53.3 \%$ showed a positive result against the test bacteria [25]. Twenty isolates (36.4\%) of 55 were potent against the test bacterial organisms. Thirteen isolates showed a positive result to more than one genus, only one isolate showed positive result against all four species of Shigella, seven isolates showed antibacterial activity against three species of Shigella and not with Shigella sonnei [26]. Even, our actinomycetes could produce the antibacterials at less percentage; they work even at very low concentrations.

India is one of the richest wealth of long seacoast and a good source of marine wealth [27]. Marine sponge-associated bacterial isolates have been evidenced as the sources for the production bioactive compounds [28]. Antimicrobial agents contribute themselves significantly in $20^{\text {th }}$ century, especially therapeutics.

Ethyl acetate extract of the actinomycetes was used in this study, ethyl acetate extract of Bergenia ciliata showed the highest zone of inhibition (7.5 mm) against B. megaterium, moderate activities against Nocardia tenerifensis and B. subtilis with $6.2 \mathrm{~mm}$ and $5.5 \mathrm{~mm}$ zone of inhibitions, respectively [29]. Ethyl acetate extract of endophytic fungi Fusarium sp. showed the best result against E. coli (microbial type culture collection [MTCC] 443) by generating $20.66 \pm 0.57 \mathrm{~mm}$ diameter zone of inhibition. The same extract created $15.66 \pm 0.57 \mathrm{~mm}, 14.66 \pm 0.57 \mathrm{~mm}$, $13.66 \pm 0.57 \mathrm{~mm}$, and $12.66 \pm 0.57 \mathrm{~mm}$ diameter zone of inhibition against P. aeruginosa (MTCC 424), K. pneumoniae (MTCC 452), Sphingomonas paucimobilis (MTCC 6363), and Proteus vulgaris (MTCC 426) [30]. Ethyl acetate extract is more potent and highly active on the bacterial organisms.

Among all four actinomycetes, the highest zone of inhibition was recorded by isolate PMA2 against Salmonella typhi $(26 \pm 0.71 \mathrm{~mm})$. Lowest zones of inhibitions were recorded by PMA2 against
K. pneumonia $(12 \pm 0.88 \mathrm{~mm})$, isolate PMA6 against $K$. pneumonia $(10 \pm 0.57 \mathrm{~mm}), 10 \pm 0.45 \mathrm{~mm}$ against $S$. epidermidis by the isolate PMA9, $8 \pm 0.56 \mathrm{~mm}$ and $8 \pm 0.19 \mathrm{~mm}$ against $B$. cereus and S. aureus, respectively, by the isolate PMA13. Kocuria kristinae produced highest zone of inhibition against B. cereus $(10.2 \mathrm{~mm})$, whereas Streptomyces flaveolus produced a very low zone of inhibition $(2.5 \mathrm{~mm})$ against K. pneumonia [2]. K. pneumonia is more sensitive to isolate PMA2 and isolate PMA6 than S. flaveolus.

B. subtilis was not inhibited by all four organisms and B. megaterium and $S$. aureus were inhibited by all four organisms. P. aeruginosa was inhibited only by the isolate PMA6 and S. epidermidis was inhibited only by isolate PMA9. The leaves and twigs extracts of Capparis cartilaginea Decne had weaker antibacterial activity against $S$. aureus and no activity against $E$. coli [31]. E. coli was not inhibited by all 12 strains, moderate to high activity was recorded by all 12 strains against $B$. cereus and only one strain can able to inhibit K. pneumonia [2], whereas E. coli is inhibited by isolate PMA2 and isolate PMA13. Isolate PMA2 could inhibit E. coli even at low concentration and high concentration of isolate PMA13 is needed to inhibit the same bacterial organism.

India like developing countries identifies the new drugs from natural sources. Few antibiotics like tetracycline are extracted from soil actinomycetes [32]. Microorganisms are the good source of enzymes, antimicrobials and they are helpful for the production of various industrial products [8]. It is vital to develop alternative drugs for the treatment of infectious diseases [33].

The sediments of Pichavaram mangroves possess certain important chemical compounds and serve as nutraceuticals, pharmaceuticals, and antimicrobials. These antimicrobials have been recommended to treat various diseases. Natural antimicrobials have greater potential applications and contribute a significant impact on health-care system of human beings and to prevent various diseases [34].

\section{CONCLUSION}

The present findings of the study gives a scientific application of the mangrove sediment as antimicrobials and commonly used for various microbial based diseases. Further, we concluded that these natural antimicrobials are the alternatives for synthetic antimicrobial drugs.

\section{ACKNOWLEDGMENTS}

The authors are thankful to the Head, Department of Biotechnology, Principal, and Management of K. S. Rangasamy College of Arts and Science (Autonomous), Tiruchengode, for providing necessary laboratory facilities during the study period. 


\section{AUTHORS' CONTRIBUTIONS}

M. Aarthi working as an Assistant Professor in the Department of Biotechnology, K. S. Rangasamy College of Arts and Science, Tiruchengode, Tamil Nadu, designed and performed the experiments. Dr. V. Balakrishnan, Assistant Professor in the Department of Botany, Arignar Anna Government Arts College, Namakkal, supervise work and manuscript work and review process. Dr. D. Kamalanathan, Assistant Professor in the department of Biotechology, K S Rangasamy College of Arts and Science, Tiruchengode, Tamilnadu. Helped to analyze the data and to write the paper. All authors read and approved the final manuscript.

\section{CONFLICTS OF INTEREST}

The authors declare that they have no conflicts of interest.

\section{FUNDING}

The work is not funded by any government funding agencies.

\section{REFERENCES}

1. Ganesan P, Reegan AD, David RH, Gandhi MR, Paulraj MG, Al-Dhabi NA, et al. Antimicrobial activity of some actinomycetes from Western Ghats of Tamil Nadu, India. Alex J Med 2017;53:101-10.

2. Elbendary AA, Hessain AM, El-Hariri MD, Seida AA, Moussa IM, Mubarak AS, et al. Isolation of antimicrobial producing Actinobacteria from soil samples. Saudi J Biol Sci 2018;25:44-6.

3. Benhadj M, Gacemi-Kirane D, Menasria T, Guebla K, Ahmane Z. Screening of rare actinomycetes isolated from natural wetland ecosystem (Fetzara Lake, Northeastern Algeria) for hydrolytic enzymes and antimicrobial activities. J King Saud Univ Sci 2019;31:706-12.

4. Manilal A, Sujith S, Selvin J, Kiran GS. Antibacterial activity of Falkenbergia hillebrandii (born) from the Indian coast against human pathogens. Phyton 2009;78:161-6.

5. Freeman BC, Beattie GA. An overview of plant defenses against pathogens and herbivores. Plant Health Instruct 2008. DOI: 10.1094/ PHI-I-2008-0226-01.

6. Suresh M, Mohammad SA, Pradipta KR, Panneerselvam A, Thajuddin N. Screening and antibacterial efficacy of selected Indian medicinal plants. Asian Pac J Trop Biomed 2016;6:185-91.

7. Kumar PS, Duraipandiyan V, Ignacimuthu S. Isolation, screening and partial purification of antimicrobial antibiotics from soil Streptomyces sp. SCA7. Kaohsiung J Med Sci 2014;30:435-46.

8. Aarthi M, Eswaran P, Rajeshkumar MP, Balakrishnan V. Isolation and characterization of gelatinase producing halophilic Bacteria from the sediments of pichavaram mangrove forest, Tamil Nadu state, South India. Res Rev 2019;9:63-70.

9. Zothan P, Passari AK, Chandra P, Leo VV, Mishra VK, Kumar B, et al. Production of potent antimicrobial compounds from Streptomyces cyaneofuscatus associated with fresh water sediment. Front Microbiol 2017;8:68

10. Stephenson FH. Calculations for Molecular Biology and Biotechnology, A Guide to Mathematics in the Laboratory. $2^{\text {nd }}$ ed. United States: Elsevier Inc., Academic Press; 2010

11. Rao AS, Shobha KL, Shetty MS, Pai KS. In vitro antibacterial and antifungal activities of aqueous and ethanolic leaf extracts of Acacia auriculiformis. Asian J Pharm Clin Res 2018;11:480-2.

12. Akhtar MS, Hossain MA, Said SA. Isolation and characterization of antimicrobial compound from the stem bark of the traditionally used medicinal plant Adenium obesum. J Tradit Complement Med 2017:7:296-300.

13. Mathur N, Paliwal A, Sharma P, Kumar M, Bhatnagar P. Antimicrobial compound from Streptomyces isolate characterized using HPLC. Univ J Environ Res Technol 2012;4:242-6.

14. Jayasree P, Thiruchelvi R, Balashanmugam P. Evaluation of antibacterial, antioxidant and anticancer potentials from marine red algae Gracilaria corticata. Asian J Pharm Clin Res 2018;11:347-50.

15. Ram D, Devang P. Screening and characteristic study of antimicrobial actinomycetes from nearby soil of medicinal plants. Int J Pharm Pharm Sci 2018;10:66-73

16. Kumar C, Sharmila KJ. Comparative study of wound healing activity of Indian medicinal plant and herb against diabetic foot ulcer (Piper nigrum and Arachis hypogaea). Asian J Pharm Clin Res 2019;12:35-9.

17. Sudha SK, Hemalatha R. Isolation and screening of antibiotic producing actinomycetes from garden soil of Sathyabama University, Chennai. Asian J Pharm Clin Res 2015;6:110-4.

18. Sengul M, Yildiz H, Gungor N, Cetin B, Eser Z, Ercisli S. Total phenolics content, antioxidant and antimicrobial activities of some medicinal plants. Pak J Pharm Sci 2009;22:102-6.

19. Chopra RN, Nayer SL, Chopra IC. Glossary of Indian Medicinal Plants. $3^{\text {rd }}$ ed. New Delhi: Council of Scientific and Industrial Research; 1992.

20. Bruneton J. Pharmacognosy Phytochemistry Medicinal Plants. France: Lavoisier Publishing Co.; 1995.

21. Khalil MY, Moustafa AA, Naguib NY. Growth, phenolic compounds and antioxidant activity of some medicinal plants grown under organic farming condition. World J Agric Sci 2007;3:451-7.

22. Dushyant S, Reena R, Monika C, Yadav JP. Antibacterial capacity and identification of bioactive compounds by GCMS of Allium cepa. Int J Pharm Pharm Sci 2018;10:116-21

23. Idrus HH, Hatta M, Febriza A, Kasim VN. Antibacterial activities of Sapodilla fruit extract inhibiting Salmonella typhi on mice BalB/C. Int J Appl Pharm 2019;11:121-6.

24. Islam MS, Islam MS, Hossain MA, Ahmed S, Aktaruzzaman M, Akanda MR, et al. In vitro antibacterial activity of medicinal plants turmeric, chinnamon and clove against GM (+ve) and GM (-ve) Bacteria. Int J Curr Pharm Res 2019;11:85-8

25. Rahman A, Islam Z, Islam A. Antibacterial activities of actinomycete isolates collected from soils of Rajshahi, Bangladesh. Biotechnol Res Int 2011;2011:1-6.

26. Arifuzzaman M, Khatun MR, Rahman H. Isolation and screening of actinomycetes from Sundarbans soil for antibacterial activity. Afr J Biotechnol 2010;9:4615-9.

27. MPEDA, NACA. Shrimp Health Management Extension Manual. Kochi, India: MPEDA, NACA; 2003.

28. Wahyudi AT, Priyanto JA, Wulandari DR, Astuti RI. In vitro antibacterial activities of Marine sponge associated Bacteria against pathogenic Vibrio spp causes vibriosis in shrimps. Int J Pharm Pharm Sci 2019;11:33-7.

29. Mithilesh S, Neha P, Vasudha A, Singh KK, Anitha P. Antioxidant, antimicrobial activity and bioactive compounds of Bergenia ciliate Sternb: A valuable medicinal herb of Sikkim Himalaya. J Tradit Complement Med 2017;7:152-7.

30. Deependra T, Kamana S. In vitro antimicrobial activity and MIC of the extracellular ethylacetate crude extract of endophytic fungi Fusarium sp. isolated from Tephrosia purpurea root. Int $\mathrm{J}$ Pharm Pharm Sci 2019;11:48-53

31. Bushra AK, Al-Mahbashi HM, Riyadh SA, Faten AA. Phytochemical, anti-inflammatory, antioxidant, cytotoxic and antibacterial study of Capparis cartilaginea Decne from Yemen. Int J Pharm Pharm Sci 2018;10:38-44.

32. Tripathi KD. Essential Medical Pharmacology. $6^{\text {th }}$ ed. New Delhi: Jaypee Brothers Medical Publishers Ltd.; 2008.

33. Shobha KL, Rao AS, Pai KS, Sujatha B. Antimicrobial activity of aqueous and ethanolic leaf extracts of Anacardium occidentale. Asian J Pharm Clin Res 2018;11:474-6.

34. Baruah IC, Barua M. Non-conventional food plants of medicinal use in Northeast India. In: Borthakur SK, Ahmed A, Gogoi P, Dutta DN, Ahmed GU, editors. Medicinal Plants of Northeast India. Guwahati, Assam: North Eastern Development Finance Corporation Ltd.; 2010. 